\title{
Contaminants in Urban Waters-Science Capabilities of the U.S. Geological Survey
}

Streams and estuaries with urban watersheds commonly exhibit increased streamflow and decreased base flow; diminished streamchannel stability; excessive amounts of contaminants such as pesticides, metals, industrial and municipal waste, and combustion products; and alterations to biotic community structure. Collectively, these detrimental effects have been termed the "urban-stream syndrome." Water-resource managers seek to lessen the effects on receiving water bodies of new urban development and remediate the effects in areas of existing urbanization. Similarly, the scientific community has produced extensive research on these topics, with researchers from the U.S. Geological Survey (USGS) leading many studies of urban streams and the processes responsible for the urban-stream syndrome. Increasingly, USGS studies are evaluating the effects of management and restoration activities to better understand how urban waters respond to the implementation of management practices. The USGS has expertise in collecting and interpreting data for many physical, chemical, and ecological processes in urban waters and, thus, provides holistic assessments to inform managers of urban water resources.

\section{Expertise and Resources}

The USGS scientists of the Northeast Region Urban Landscapes Capability Team share expertise and resources to provide and interpret data on a wide range of urban-related issues at local, regional, and national levels. Monitoring contaminants in urban waters is one such area of expertise. The USGS develops and uses nationally-consistent methods for sampling and continuous monitoring. Scientists with the USGS work with stakeholders and industry to develop specialized sampling equipment, such as automated and passive samplers, for use in rivers, streams, estuaries, and groundwater. The USGS laboratories have developed state-of-the-art analytical methods for environmental samples such as the methods used to detect pharmaceuticals and pesticides and to operate at production levels supportive of USGS activities nationwide. Data generated by these monitoring and analytical programs are retained by the USGS National Water Information System database (http://dx.doi.org/10.5066/ F7P55KJN). Scientists and statisticians of the USGS develop and utilize cutting-edge modeling and statistical analysis tools to interpret the data that result from these monitoring activities. This combination of nationally-consistent data-collection methods, centralized laboratory services, and advanced interpretive capabilities are unparalleled outside of the USGS. These capabilities have been relied on by resource managers to determine the effectiveness of stormwater-management infrastructure (including green infrastructure effectiveness), evaluate improvements in wastewater-treatment processes, and evaluate the feasibility of water reuse.

\section{Nutrients}

The overenrichment of nutrients in an ecosystem, which is termed eutrophication, creates a detrimental imbalance of the ecosystem. Though often associated with agricultural watersheds, eutrophication is common in urban streams and also in

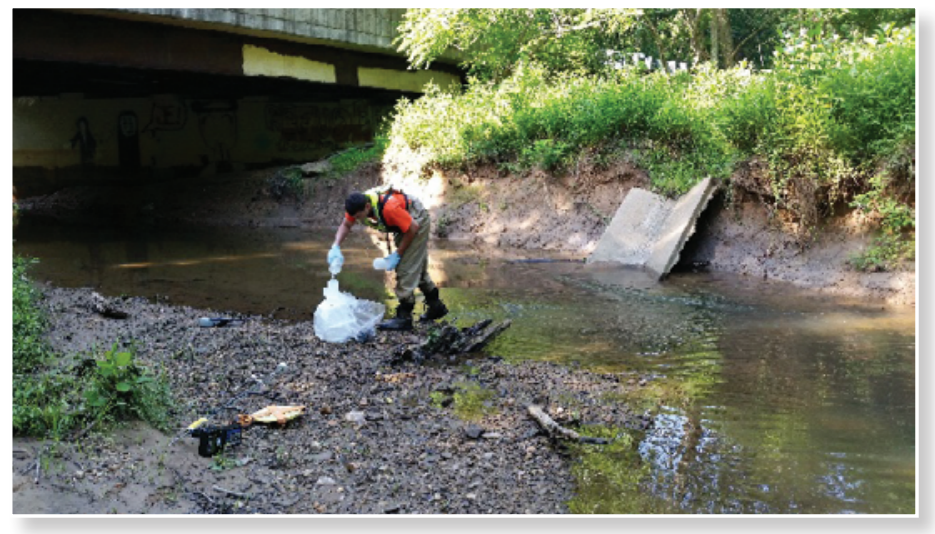

A U.S. Geological Survey scientist collecting a water-quality sample in an urban stream in Virginia. Photograph by U.S. Geological Survey.

receiving water bodies. Eutrophication is the result of over-application of fertilizers on urban turf, leaking municipal sewer infrastructure, increased density of septic systems, and other nutrient sources. The USGS has expertise in monitoring nutrients and in modeling loads and trends using a combination of traditional methods and advanced technologies. Additional USGS expertise pertaining to nutrient cycles in the urban environment includes identifying nutrient sources and assessing the effectiveness of management mitigation actions.

\section{Suspended Sediment}

Sediment loads can increase dramatically in watersheds undergoing urbanization because of increased sediment-laden runoff and because of aggravated erosion of stream channels that have more frequent high-energy stormflow events. Increases in sediment loads are often associated with destabilization of stream channels and degradation of habitat quality and also increases in the transport of sediment-associated contaminants. The USGS expertise in sediment-generation and transport 
related issues in urban streams includes geomorphic watershed assessment and monitoring; suspended sediment and sedimentassociated contaminant loads, yields, and trends monitoring; and application of state-of-the-art continuous monitoring technologies.

\section{Toxic Substances}

Anthropogenic activities in urban areas release a broad range of chemical substances to the environment. Contamination by these substances, which include pesticides; pharmaceuticals; detergents and surfactants; fire suppressants; polychlorinated biphenyls; metals; and biological constituents such as bacteria, viruses, and other pathogens, can result in environmental degradation as well as effects to human health. Through programs such as the Toxic Substances Hydrology Program (http://toxics.usgs.gov/), the USGS has developed extensive expertise in characterizing the processes that control contaminant transport and degradation in aquatic environments, including methods of measuring and modeling these contaminants and their transport and fate.

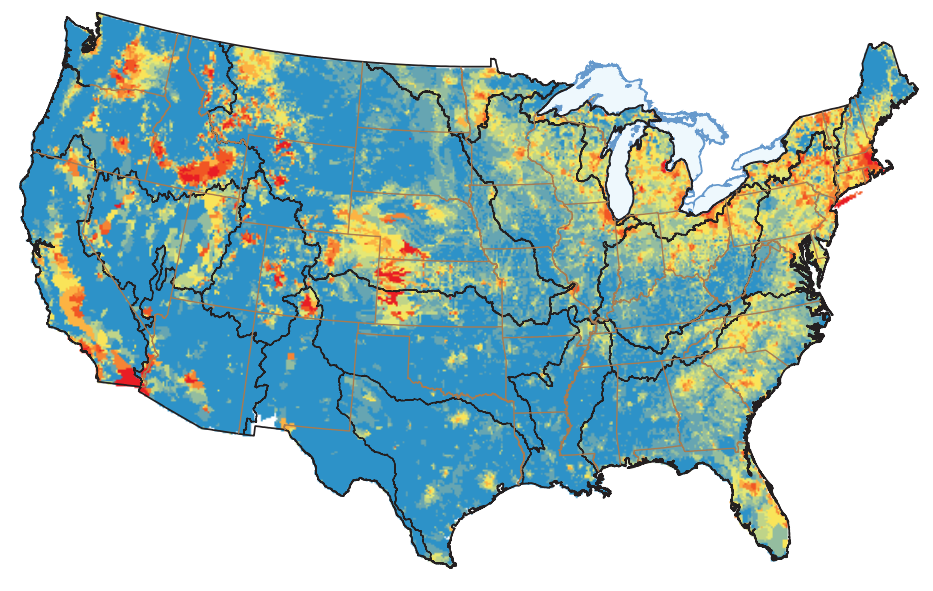

EXPLANATION

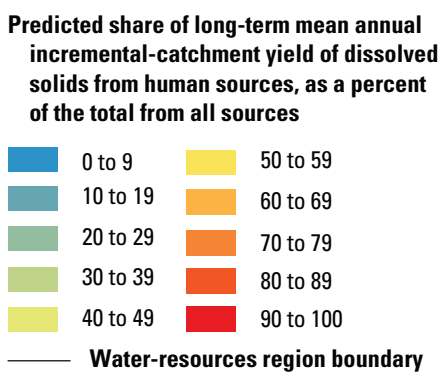

The U.S. Geological Survey spatially referenced regressions on watershed model (also known as SPARROW) has been used to predict the percentage of dissolved solids yields contributed from human sources throughout the conterminous United States. Percentages represented by the color gradient from 0 to 100 percent of contribution. Note the widespread areas of greater human sources throughout the densely populated northeastern United States. From Anning and Flynn (2014).

\section{Contaminants of Emerging Concern}

Contaminants of emerging concern are natural or synthetic chemicals that commonly have been monitored in the environment but have the potential to enter the environment and are known or suspected to cause adverse environmental or human health effects. This class of contaminants includes potential endocrine disrupting compounds such as hormones, pharmaceuticals, personal-care products, pesticides, and other compounds that are associated with human activity and, therefore, commonly are detected in many densely populated urban areas. The USGS has pioneered many of the methods used for sample collection and analyses of these compounds in natural waters.

\section{Examples of Current USGS Studies of Urban Water Quality}

Scientists with the USGS are currently (2016) studying water quality in urban waters in the following areas:

- Fairfax County, Virginia-http://va.water.usgs.gov/fairfax

- Hampton Roads Region, Virginia-http://va.water.usgs.gov/ HRstormwater

- Anacostia River, Maryland-http://md.water.usgs.gov/ projects/qw/anacostia_nebranch

- Paint Branch, Maryland-http://md.water.usgs.gov/projects/ qw/paint_branch

- Bronx and Harlem Rivers, New Yorkhttp://ny.cf.er.usgs.gov/nyprojectsearch/projects/LK00DU700.html

\section{Partnering Opportunities}

The USGS is committed to expanding studies of urban streams. Access to USGS expertise, such as that described herein, is possible through numerous partnering opportunities. State and local agencies may partner with the USGS and access matching funds through the Cooperative Water Program (http://water.usgs.gov/coop/). Federal agencies, educational institutions, nonprofit organizations, and other entities may partner with USGS through a variety of programs.

\section{Reference Cited}

Anning, D.W, and Flynn, M.E., 2014, Dissolved-solids sources, loads, yields, and concentrations in streams of the conterminous United States: U.S. Geological Survey Scientific Investigations Report 2014-5012, 101 p., accessed April 12, 2016, at http://dx.doi.org/10.3133/sir20145012.

By John D. Jastram and Kenneth E. Hyer

\section{For more information about these USGS projects and about partnering opportunities, contact:}

USGS Northeast Region Urban Landscapes Capability Team

Email: GS-NE_ULCT@usgs.gov

or contact your local USGS office

https://www.usgs.gov/contact_us 